\title{
Geospatial Variability Analysis of Fluoride Quantification in Underground Aquifers of Central Parts of Haryana State, India
}

\author{
P. Bhardwaj ${ }^{1}$, A. Awasthi ${ }^{1}$, J. Singh ${ }^{2 *}$ \\ ${ }^{1}$ School of Basic and Applied Sciences, Maharaja Agrasen University, Baddi-174103, India \\ ${ }^{2}$ School of Physical Sciences, DIT University, Dehradun - 248001, India
}

Received 9 March 2021, accepted in final revised form 3 June 2021

\begin{abstract}
The elevated levels of fluoride in underground water enhance the prevalence of the fluorosis epidemic in Haryana state. To assess the groundwater geospatial variability of fluoride at different depths in central parts of Haryana, the present study has been explored. The samples at eight sites were collected in triplicate at 3 depth levels viz. a) $<10 \mathrm{~m}$ below ground level (bgl), b) 10-40 m bgl, and c) > $40 \mathrm{~m}$ bgl. Fluoride levels have been determined by the SPADANS-zirconyl oxychloride method using UV-VIS spectrophotometer (Systronics-118). The fluoride concentration varies from $0.19 \mathrm{mg} / \mathrm{L}$ to $2.87 \mathrm{mg} / \mathrm{L}$. More than 38 percent of samples exceed the standard prescribed limit of $1.0 \mathrm{mg} / \mathrm{L}$ fluoride in drinking water. Fluoride contamination increases in post-monsoon samples with maximum concentration at $40 \mathrm{bgl}$ depth. Due to geological factors (fluoride-bearing minerals in basement rocks) and human-induced (brick-kiln industries, phosphatic fertilizers) factors, a high concentration of fluoride in groundwater is observed. Sustainable defluoridation techniques and a good diet (calcium \& vitamin c enriched) can control the adverse effects of fluorosis.
\end{abstract}

Keywords: Aquifers; Depth; Fluoride; Geospatial; Groundwater; Monsoon; Permissible limit.

(c) 2021 JSR Publications. ISSN: 2070-0237 (Print); 2070-0245 (Online). All rights reserved. doi: http://dx.doi.org/10.3329/jsr.v13i3.52398

J. Sci. Res. 13 (3), 951-959 (2021)

\section{Introduction}

Groundwater is one of the most precious natural resources of our planet and plays a vital role in every facet of human life. Because of rapidly increasing population and henceforth water footprints, urbanization, groundwater overharvesting, surface water pollution, and deforestation, pressure is continuously increasing on this valuable resource of nature [1]. Groundwater is a natural resource that plays a crucial role, which accounts for nearly 80 $\%$ of the rural domestic water needs, and $50 \%$ of the urban water needs in India [2]. Groundwater is the primary source of drinking water for about $98 \%$ of the population in Haryana [1]. Due to the high concentration of fluoride in groundwater, dental fluorosis has become a common disease globally. Nearly 200 million people from 25 nations are

\footnotetext{
*Corresponding author: drjabrinder.singh@dituniversity.edu.in
} 
affected by the epidemic of fluorosis at a global level [3]. In India, excessive fluoride in groundwater is noticed in 177 districts covering 21 states, affecting 62 million people, including 6 million children [3]. In India, several areas are recognized as the red alert zone with a higher fluoride amount by the Geological Survey of India (GSI) [4]. The research explored by Subha et al. [5] and Reddy et al. [6] in Andhra Pradesh and Telangana states, respectively, mentions the exposure of about $58 \%$ human population to heavy fluoride concentrated drinking water. A study by Amanjeet et al. [7] stated that dental fluorosis in adults and children is very common in the Haryana state and symptoms of skeletal fluorosis are prominent among adults in some districts having high fluoride concentration.

After the onset of the green revolution, intensive farming practices become a depiction in Indo-Gangetic plain states, and irrigation water needs are meet up by underground harvesting [as per Haryana state govt. agencies, the cultivable area is 3.809 million hectares $(86.2 \%$ of total geographical area), and the net area sown is 3.566 million hectares (93.6\% of cultivable area]. Eventually, fluoride concentration increases in groundwater. Thus, dental and skeletal health problems become more endemic in this region [8]. Fluoride in groundwater mainly occurs because of the geomorphology and environment of the aquifer below the groundwater. Most of the districts of Haryana have rock beds of quartzite, mica, clay, and other fluoride-bearing minerals, viz. $\mathrm{CaF}_{2}$, $\mathrm{Ca}_{5}\left(\mathrm{PO}_{4}\right)_{3} \mathrm{~F}$ and $\mathrm{Na}_{3} \mathrm{AlF}_{6}$; which is the preliminary cause of fluoride existence in groundwater. Besides, it is also observed that at some sites, fluoride concentration varies depth wise. This may be attributed to the fluctuations in the water table at those sites [9]. According to health organizations [10], the permissible limit for $\mathrm{F}^{-}$concentration is 1-1.5 $\mathrm{mg} / \mathrm{L}$. As per BIS [11], the permissible limit of fluoride in potable water is $1.0 \mathrm{mg} / \mathrm{L}$. However, in the absence of an alternate source for drinking water, the maximum acceptable limit can be $1.5 \mathrm{mg} / \mathrm{L}$. Fluoride concentration less than $0.5 \mathrm{mg} / \mathrm{L}$ leads to dental caries. Hence, it is essential to maintain this micronutrient (fluoride) concentration between 0.5 to $1.0 \mathrm{mg} / \mathrm{L}$ in drinking water. As per Bhowmick [12] $\mathrm{CF}_{3}$ is also used in pharmaceutical industries. But in higher concentrations, fluoride causes dental and skeletal fluorosis. Studies conducted by different people (Table 1) indicated a high concentration of fluoride in Haryana.

Table 1. Fluoride concentration in groundwater in different parts of Haryana, India [13-23, 8].

\begin{tabular}{llll}
\hline Sr. No. & Author and ref. & Study area & Findings \\
\hline 1 & S. Mor et al. [13] & Pataudi & $0.95-2.42 \mathrm{mg} / \mathrm{L}$ \\
2 & Ravinder and Garg [14] & Hisar & $0.03-16.6 \mathrm{mg} / \mathrm{L}$ \\
3 & B. Singh [15] & Dabwali & $0.90-34.50 \mathrm{mg} / \mathrm{L}$ \\
4 & B. P. Manjeet et al. [16] & Gurgaon & $0.02-6.4 \mathrm{mg} / \mathrm{L}$ \\
5 & S. Ravish et al. [17] & Ambala / Yamunanagar & $-1.7 \mathrm{mg} / \mathrm{L}$ \\
6 & K. Haritash et al. [18] & Hisar rural & $0.05-2.4 \mathrm{mg} / \mathrm{L}$ \\
7 & Kumar and Sharma [19] & Hisar city & $0.5-2.98 \mathrm{mg} / \mathrm{L}$ \\
8 & S. Kumar et al. [20] & Jhajjar & $1.63-3.33 \mathrm{mg} / \mathrm{L}$ \\
9 & R. Kumar et al. [21] & Mahendergarh & $0.6-5.1 \mathrm{mg} / \mathrm{L}$ \\
10 & Bishnoi and Malik [22] & Panipat & $0.24-9.27 \mathrm{mg} / \mathrm{L}$ \\
11 & S. Singh et al. [23] & Jind & $0.11-2.93 \mathrm{mg} / \mathrm{L}$ \\
12 & CGWB [8] & Whole Haryana & $0.1-30 \mathrm{mg} / \mathrm{L}$ \\
\hline
\end{tabular}


Further, some researchers conducted work on the prevalence of fluorosis among children $[18,24]$. They concluded that due to the consumption of available bore water in the schools, the children are affected by dental fluorosis. Fluoride concentration varied from place to place and mostly dependent on geological and environmental factors. Till now, no efforts have been explored for variation in fluoride content at different depths in Haryana state. Henceforth, this study was conducted to assess the variation of fluoride ions at different depths in central parts of Haryana. It will pave the way for further research in investigating the fluorosis endemic problems in this region.

\section{Materials and Methods}

\subsection{Study area}

Haryana is a major agricultural state (rank $6^{\text {th }}$ in food grains production) of India with $44,212 \mathrm{Km}^{2}$, and it has regional areas of high concentration of fluoride in groundwater throughout its stretch [8]. The main sources of groundwater (hand-pump, tube-well, and submersible pump) in central parts of Haryana fulfill the domestic water needs of inhabitants. The whole Jind district and parts of Hisar, Karnal, Kaithal, Panipat, Sonipat, and Rohtak represent the central parts of the state. The main area (central Haryana) lies between 28.89' and 29.80' $\mathrm{N}$ latitude $75.72^{\prime}$ and 76.92' E longitude (Fig. 1).

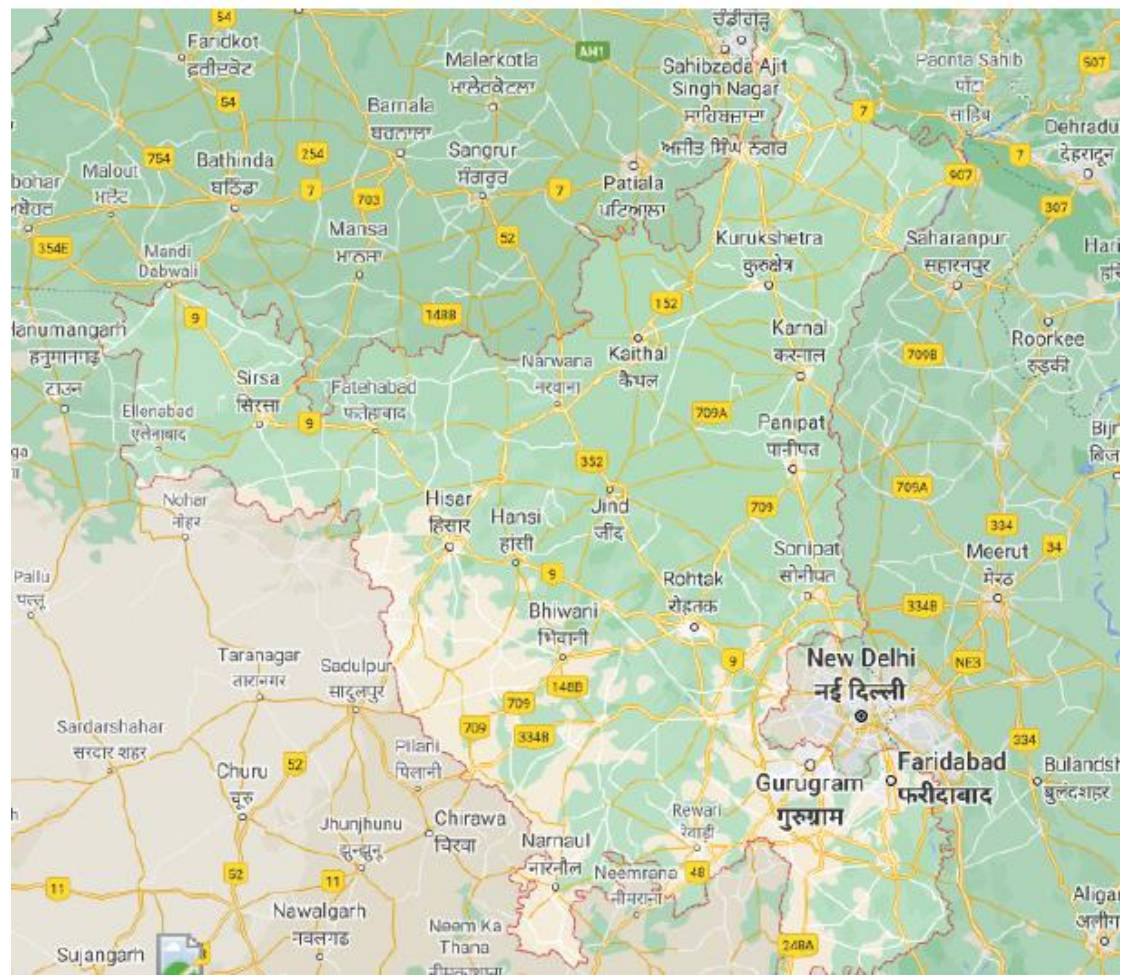

Fig. 1. Google map of the study area (Haryana State, India). 


\subsection{Collection and analysis of water samples}

Water samples from various drinking groundwater sources (hand pumps, open wells, and tube wells) were collected from various central parts of Haryana to determine fluoride levels for two consecutive years (sampling details mentioned in Table 2). Samples were collected pre-monsoon and post-monsoon to differentiate the impact of water recharging and its interaction with rocks. Geographic locations of sampling sites (total 8 sites) were mapped using the Global Positioning System (GPS). The samples at each site were collected in triplicate at three depth levels viz. a) < $10 \mathrm{~m} \mathrm{bgl}$, b) $10-40 \mathrm{~m} \mathrm{bgl}$ and c) > $40 \mathrm{~m} \mathrm{bgl}$.

Samples were collected in prewashed plastic bottles and carried to the laboratory. The collected samples were kept in the dark place at room temperature in plastic containers until the fluoride analysis was done. Fluoride in water samples was determined by the SPADANS-zirconyl oxychloride method using a UV-VIS spectrophotometer (Systronics118). The absorbance values obtained at $\lambda$ max equal to $570 \mathrm{~nm}$ were compared with the standard calibration curve for fluoride concentration.

\section{Results and Discussion}

The underground water samples were colorless, odorless, and without turbidity. Although most of the water samples collected were tasteless, it was slightly brackish at some locations due to hardness. The concentration of fluoride in sample sites at different depths is provided in Table 2 . The results indicate that the quality of water varies considerably at different depths. It has also been concluded that the underground water quality varied geospatially also. The fluoride concentration varies from $0.19 \mathrm{mg} / \mathrm{L}$ to $2.87 \mathrm{mg} / \mathrm{L}$. More than $38 \%$ of samples exceeded the standard prescribed limit of $1.0 \mathrm{mg} / \mathrm{L}$ fluoride in drinking water. Fluoride contamination increases in post-monsoon samples with maximum concentration at $40 \mathrm{bgl}$ depth. In most of the samples, it can be concluded that during post-monsoon, recharging of underground water takes place. Still, it shows interaction with rocks and fertilizer ions and increases the concentration of fluoride; it may be due to high residence time, long water-rock interaction during infiltration, etc., list all the possible factors.

Similarly, high fluoride content was observed in deep aquifers compared to shallow aquifers in Orissa state by Das et al. [25]. Among the study area, the lowest concentration was found in Hisar samples, and the highest was in Rohtak region samples (Fig. 2). Among the study area, optimum concentration was found in $48 \%$, and $38 \%$ of samples have more than the permissible limit $(1.0 \mathrm{mg} / \mathrm{L})$ fluoride concentration (Fig. 3). Spatiotemporal variation can be observed in Fig. 3b, which depicts the significant changes in fluoride amount in different locations fluctuating with the monsoon. Studies conducted by CGWB [8] in Fig. 4 also depict the high concentration of fluoride in the study area. 
Table 2. Fluoride concentration at different depths in sampling locations.

\begin{tabular}{|c|c|c|c|c|c|c|}
\hline $\begin{array}{l}\text { SL. } \\
\text { No }\end{array}$ & Sample Site & Water sample depth & $\begin{array}{c}\text { Pre- } \\
\text { monsoon } \\
2018-19\end{array}$ & $\begin{array}{c}\text { Post- } \\
\text { monsoon } \\
2018-19\end{array}$ & $\begin{array}{c}\text { Pre- } \\
\text { monsoon } \\
2019-20\end{array}$ & $\begin{array}{c}\text { Post- } \\
\text { monsoon } \\
2019-20\end{array}$ \\
\hline \multirow[t]{3}{*}{1} & \multirow{3}{*}{$\begin{array}{l}\text { Salwan } \\
\text { (Karnal) }\end{array}$} & Depth $<10 \mathrm{~m} \mathrm{bgl}$ & 0.62 & 0.27 & 0.34 & 0.29 \\
\hline & & Depth- $10-40 \mathrm{~m} \mathrm{bgl}$ & 0.58 & 0.79 & 0.75 & 0.77 \\
\hline & & Depth $>40 \mathrm{~m}$ bgl & 0.69 & 1.39 & 0.81 & 0.89 \\
\hline \multirow[t]{3}{*}{2} & \multirow{3}{*}{$\begin{array}{l}\text { Didwara } \\
\text { (Panipat) }\end{array}$} & Depth $<10 \mathrm{~m}$ bgl & 0.54 & 1.66 & 2.01 & 1.92 \\
\hline & & Depth- $10-40 \mathrm{~m}$ bgl & 0.68 & 1.56 & 0.73 & 1.28 \\
\hline & & Depth $>40 \mathrm{~m}$ bgl & 0.56 & 0.86 & 0.81 & 0.66 \\
\hline \multirow[t]{3}{*}{3} & \multirow{3}{*}{$\begin{array}{l}\text { Kaithal } \\
\text { City }\end{array}$} & Depth $<10 \mathrm{~m}$ bgl & 0.79 & 1.02 & 0.38 & 0.78 \\
\hline & & Depth- 10-40m bgl & 0.79 & 0.94 & 0.38 & 0.98 \\
\hline & & Depth > 40m bgl & 0.71 & 0.8 & 1.54 & 1.23 \\
\hline \multirow[t]{3}{*}{4} & \multirow{3}{*}{$\begin{array}{l}\text { Jhanj Kalan } \\
\text { (Jind) }\end{array}$} & Depth $<10 \mathrm{~m}$ bgl & 0.36 & 0.71 & 0.65 & 0.62 \\
\hline & & Depth- 10-40m bgl & 0.32 & 0.99 & 0.53 & 0.82 \\
\hline & & Depth $>40 \mathrm{~m}$ bgl & 0.74 & 2.62 & 2.2 & 2.68 \\
\hline \multirow[t]{3}{*}{5} & \multirow{3}{*}{$\begin{array}{l}\text { Ashraf } \\
\text { Garh (Jind) }\end{array}$} & Depth $<10 \mathrm{~m}$ bgl & 0.66 & 0.98 & 0.79 & 0.84 \\
\hline & & Depth- $10-40 \mathrm{~m} \mathrm{bgl}$ & 0.78 & 0.9 & 0.81 & 0.88 \\
\hline & & Depth $>40 \mathrm{~m}$ bgl & 0.59 & 1.71 & 1.02 & 1.32 \\
\hline \multirow[t]{3}{*}{6} & \multirow{3}{*}{$\begin{array}{l}\text { Dhani Garn } \\
\text { (Hisar) }\end{array}$} & Depth $<10 \mathrm{~m}$ bgl & 0.59 & 2.74 & 2.2 & 2.52 \\
\hline & & Depth- 10-40m bgl & 0.43 & 2.7 & 1.17 & 2.82 \\
\hline & & Depth $>40 \mathrm{~m}$ bgl & 0.38 & 2.02 & 0.19 & 1.45 \\
\hline \multirow[t]{3}{*}{7} & \multirow{3}{*}{$\begin{array}{l}\text { Pauli } \\
\text { (Rohtak) }\end{array}$} & Depth $<10 \mathrm{~m}$ bgl & 0.89 & 1.61 & 1.42 & 1.35 \\
\hline & & Depth- $10-40 \mathrm{~m}$ bgl & 0.8 & 2.54 & 1.02 & 1.07 \\
\hline & & Depth $>40 \mathrm{~m}$ bgl & 0.79 & 2.87 & 0.6 & 0.9 \\
\hline \multirow[t]{4}{*}{8} & \multirow{3}{*}{$\begin{array}{l}\text { Bali } \\
\text { (Sonepat) }\end{array}$} & Depth $<10 \mathrm{~m}$ bgl & 0.32 & 0.63 & 0.29 & 0.42 \\
\hline & & Depth- 10-40m bgl & 1.13 & 0.81 & 1.03 & 1.12 \\
\hline & & Depth $>40 \mathrm{~m}$ bgl & 1.65 & 1.92 & 1.09 & 1.07 \\
\hline & Mean & & 0.68 & 1.46 & 0.94 & 1.19 \\
\hline
\end{tabular}

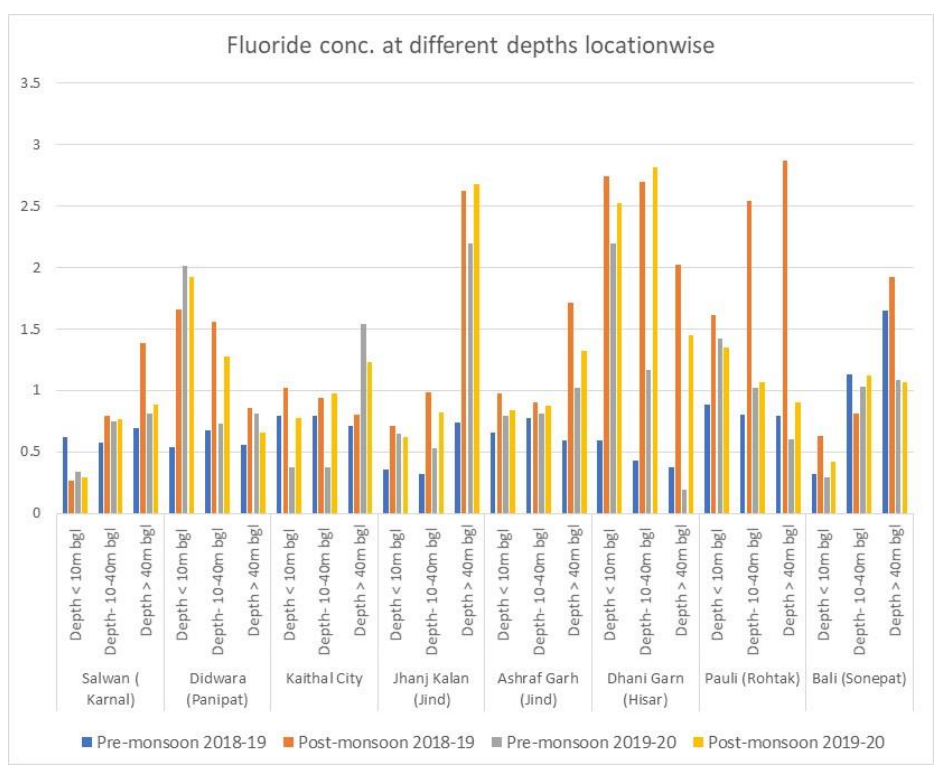

Fig. 2. Comparative graphical portray of fluoride concentration at different depths in all sites. 


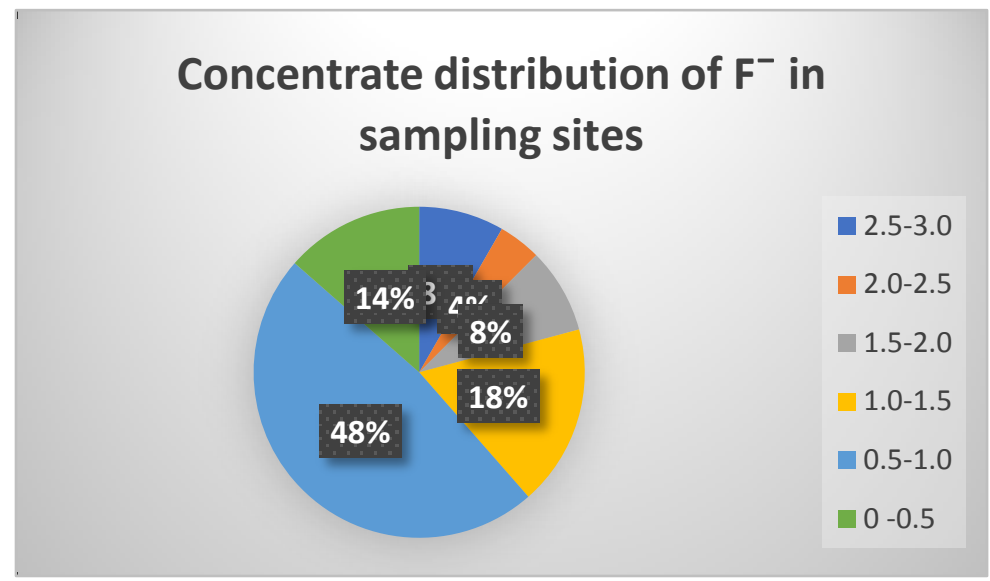

Fig. 3a. Percent distribution of sampling locations according to $\mathrm{F}^{-}$levels.

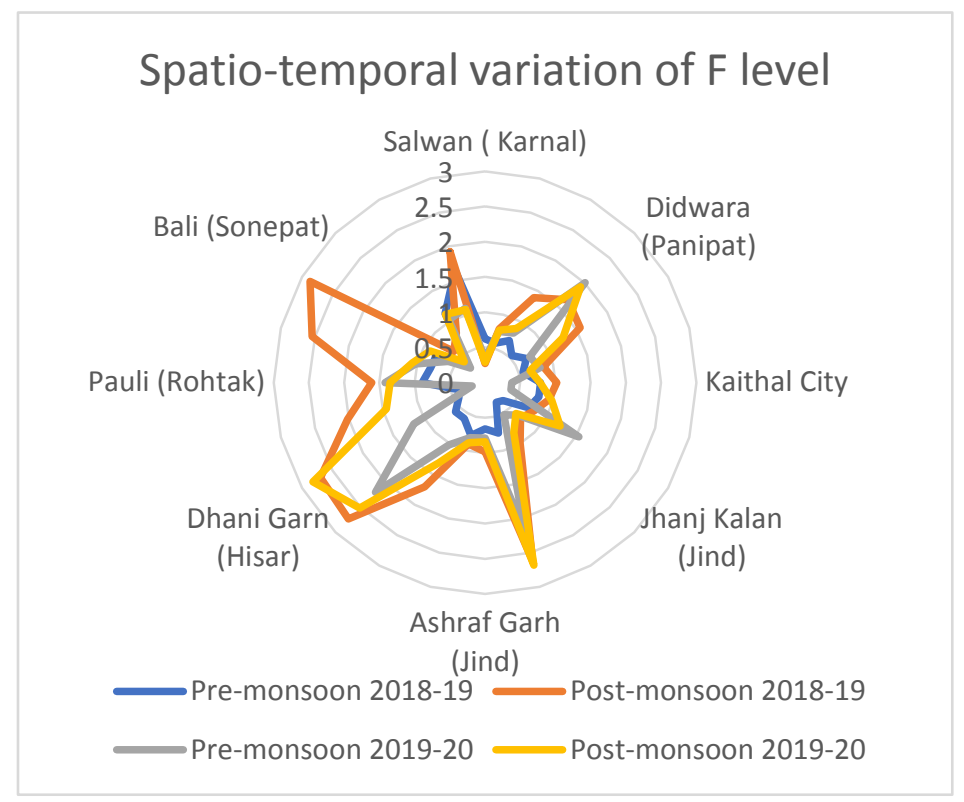

Fig. 3b. Spatio-temporal variation of $\mathrm{F}^{-}$levels in sampling locations.

High fluoride concentration in drinking water led to dental and skeletal fluorosis. In Haryana state, dental and skeletal fluorosis epidemic is observed among the human population due to consumption of underground water with high content of fluoride [8].

Various studies indicate a positive correlation of fluoride concentration with $\mathrm{Na}^{+}$, $\mathrm{HCO}_{3}{ }^{-}, \mathrm{Ca}^{2+}$, TDS, TA, EC $[15,19,20]$. It signifies the possible presence of fluorspar, fluorapatite, cryolite under soil strata/rocks. Thus, a high concentration of fluoride in underground water may be attributed to the geological and anthropogenic environment of the area. Different studies support these facts. The major fluoride sources in groundwater 
are fluoride-bearing rocks, such as fluorspar, cryolite, fluorapatite, and hydroxylapatite [26]. Fluoride ions from these minerals leach into the groundwater and contribute to high fluoride concentrations [27,28].

Further overexploitation of underground water for irrigation needs in central Haryana enhances the problem by lowering the water table. Every year level of groundwater continuously goes down as per CGWB reports [8]. This report also suggests that fluoride above $1.5 \mathrm{mg} / \mathrm{L}$ is observed in areas where agricultural activities are dominant.

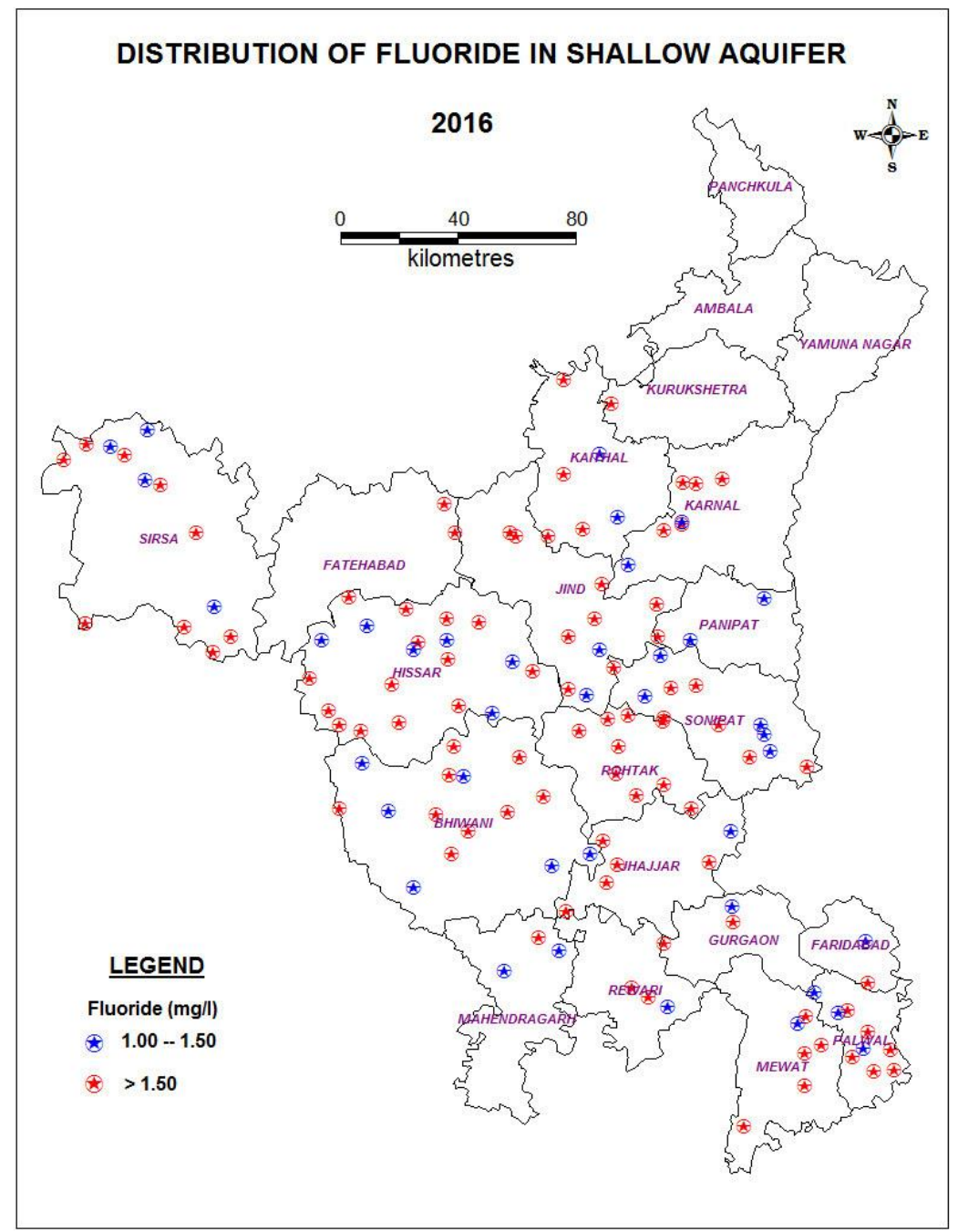

Fig. 4. Fluoride concentration in Haryana (CGWB) [8].

The likely causes for high fluoride in groundwater may be due to leaching of phosphatic fertilizers and depletion of calcium either due to precipitation or exchange phenomenon as per CGWB reports [8]. Among the various sources of fluoride in the 
environment, anthropogenic origins have occasionally been considered major ones, such as brick-kiln industries, phosphatic fertilizer plants, and agri-run-off [29]. Various costeffective and simple procedures (Nalgonda Technique; F- Adsorbents; Recharging groundwater with rainwater) for water defluoridation are already known, but the benefits of such techniques have not reached the rural areas due to various limitations. A practical alternative to mitigate the problem of fluorosis is a nutrient-enriched diet for the affected population. As per Yadav et al. [30], foodstuff with rich calcium and vitamin C content can prevent fluorosis to a certain extent.

\section{Conclusion}

The study demonstrates that central parts of Haryana comprise higher levels of fluoride in underground water samples. The concentration fluctuates with depth \& location as well as season-wise too. As the water table continuously depletes due to the overharvesting of groundwater, the implications of high fluoride content to the population also increase. Further geological studies can be explored to rule out the problem of high fluoride levels in underground aquifers. Sustainable defluoridation techniques must be adopted to ensure safe drinking water for the inhabitants. Apart from removal techniques, ill-consequences of excess intake of fluoride can be reduced by good diet and nutrition (calcium \& vitamin $\mathrm{C}$ enriched), which can control the damaging effect of fluorosis. Thus, the best method of mitigating fluorosis is to implement defluoridation techniques in the affected areas and change the dietary habits of vulnerable people from the lower-income group. Therefore, public health and other concerned departments must develop workable strategies to provide fluoride-safe drinking water to rural communities.

\section{References}

1. Sitender and B. S. Chaudhary, Int. J. Adv. Rem. Sens. GIS and Geog. 3, 26 (2015).

2. R. Kumar, R. D. Singh, and K. D. Sharma, Curr. Sci. 89, 794 (2005).

3. N. Adimalla and S. Venkatayogi, Appl. Water Sci. 8, 44 (2018). https://doi.org/10.1007/s13201-018-0682-1

4. S. Yadav, S. Kumar, S. Yadav, and S. Kumar, Appl. Water Sci. 9, 62 (2019). https://doi.org/10.1007/s13201-019-0935-7.

5. N. S. Rao, P. S. Rao, A. Dinakar, P. V. N. Rao, and D. Marghade, Appl. Water Sci. 7, 1467 (2017). https://doi.org/10.1007/s13201-015-0338-3

6. K. K. Reddy, D. K. Sahadevan, H. Gupta, and D. V. Reddy, J. Earth Syst. Sci. 128, 132 (2019). https://doi.org/10.1007/s12040-019-1151-4

7. Amanjeet, A. Kumar, and S. Kumar, Int. J. Res Manag. Sci. Tech. 5, 59 (2017).

8. Central Ground Water Board, Ground Water Quality in Shallow Aquifers of India (CGWB, New Delhi, 2017).

9. R. Gupta and A. K. Misra, Study of Civil Eng. Arch. 3, 24 (2014).

10. World Health Organization, Guidelines for Drinking-Water Quality (WHO, Geneva, 2006).

11. Bureau of Indian Standards, Indian standard drinking water specifications BIS 10500 (BIS, New Delhi, 2012).

12. A. C. Bhowmick, J. Sci. Res. 13, 317 (2021). http://dx.doi.org/10.3329/jsr.v13i1.48992

13. S. Mor, S. Singh, and P. Yadav, Environ. Geochem. Health 31, 643 (2009). https://doi.org/10.1007/s10653-008-9222-5 
14. K. Ravindra and V. K. Garg, Int. J. Environ. Health Res. 16, 163 (2006). https://doi.org/10.1080/09603120500538283

15. B. Singh, Univ. J. Environ. Res. Technol. 1, 45 (2011). https://doi.org/10.1021/es201706w

16. Manjeet, B.P. Singh, and J. K. Sharma, Int. J. Innov. Res. Sci. Eng. Tech. 3 (2014).

17. S. Ravish, B. Setia, and S. Deswal - Indian Conference on Geotechnical and GeoEnvironmental Engineering (MNNIT Allahabad, India, 2019).

18. A. K. Haritash, A. Agarwal, J. Soni, K. Sharma, M. Sapra, and B. Singh, Appl. Water Sci. 8, 52 ( 2018). https://doi.org/10.1007/s13201-018-0691-0

19. S. Kumar and S. K. Sharma, Int. J. Chem. Sci. 15, 183 (2017).

20. S. Kumar, S. Lata, J. Yadav, and J. P. Yadav, Appl. Water Sci. 7, 3377 (2017). https://doi.org/10.1007/s13201-016-0492-2

21. R. Kumar, K. Neerja, S. S. Yadav, and S. S. Biomed, J. Sci. Tech. Res. 1 (2017).

22. M. Bishnoi and R. Malik, J. Environ. Biol. 29, 881 (2008).

23. S. Singh, P. Singh, R. Kumar, and S. Saharan, J. Water Res. Prot. 4, 39 (2012). https://doi.org/10.4236/jwarp.2012.41006

24. J. P. Yadav, S. Lata, S. K. Kataria, and S. Kumar, Environ. Geochem. Health 31, 431 (2009). https://doi.org/10.1007/s10653-008-9196-3

25. S. Das, B.C. Mehta, S.K. Samanta, P.K. Das and S.K. Srivastava, Ind. J. of Environ Hlth. 1, 40 (2000).

26. V. Agarwal, A. K. Vaish, and P. Vaish, Curr. Sci. 73, 743 (1997).

27. S. S. Latha, S. R. Ambika, and S. J. Prasad, Curr. Sci. 6, 730 (1999).

28. V. Ramesam and K. J. Rajagopalan, J. Geol. Soc. 26, 125 (1985).

29. S. K. Jha, V. K. Mishra, D. K. Sharma, and T. Damodaran, J. Toxicol Environ. Health B Crit. Rev. 16, 52 (2013). https://doi.org/10.1080/10937404.2013.769420

30. N. Yadav, K. Rani, S. S. Yadav, V. K. Yadav, and N. Yadav, Int. J. Curr. Microbiol. App. Sci. 7, 1147 (2018). https://doi.org/10.20546/ijcmas.2018.705.140 